\title{
Beroepsziektemeldingen vanwege COVID-19 bij NCVB
}

Sietske Tamminga, Marijke Schutte, Steven Visser, Sanja Kezic, Gerda de Groene, Jaap Maas, Astrid de Wind, Henk van der Molen

\begin{abstract}
Achtergrond en doel
Coronavirus Infectious Disease (COVID-19) houdt Nederland al ruim een half jaar in zijn greep. Het komt zelden voor dat in Nederland een nieuwe ziekte zo snel is geïntroduceerd, met zo'n grote maatschappelijke ontwrichting, morbiditeit en mortaliteit. ${ }^{1}$ De eerste officiële registratie van een COVID-19-patiënt door het Rijksinstituut voor Volksgezondheid en Milieu (RIVM) in Nederland was eind februari 2020. Omdat blootstelling aan het Severe Acute Respiratory Syndrome-Coronavirus type 2 (Sars-Cov-2 virus) ook in het werk kan plaatsvinden ${ }^{1}$, kan COVID-19 in voorkomende gevallen als een beroepsziekte worden gemeld. Het doel van dit artikel is een overzicht geven uit welke sectoren deze meldingen komen en wat de karakteristieken zijn van de werknemers die gemeld zijn met COVID-19.
\end{abstract}

\section{Methode \\ Voor dit artikel inventariseerden we de beroepsziekte- meldingen COVID-19 die tot en met eind oktober 2020 binnen zijn gekomen bij het NCVB. Om vast te kunnen stellen of besmetting met COVID-19 gemeld moet worden als beroepsziekte hebben bedrijfsartsen en data-experts een kort stappenplan gemaakt, gebaseerd op het bestaan- de zes-stappenplan voor het vaststellen van een beroeps- ziekte. ${ }^{2}$ In het stappenplan is opgenomen dat COVID-19 gemeld kan worden als beroepsziekte, met vermelding van de bron van besmetting en de bijkomende klachten. Dit stappenplan is in maart 2020 gecommuniceerd via de website van het $\mathrm{NCVB}^{3}$ en via een nieuwsbrief verspreid onder alle bedrijfsartsen in Nederland. \\ De karakteristieken die vermeld worden bij deze COVID-19-meldingen zijn leeftijd, sekse, economische}

Sietske J. Tamminga, Marijke Schutte, Steven Visser, Sanja Kezic, Gerda de Groene, Jaap Maas, Astrid de Wind, Henk F. van der Molen werken bij Amsterdam UMC, locatie AMC, Universiteit van Amsterdam, Public and Occupational Health, Coronel Instituut voor Arbeid en Gezondheid, Nederlands Centrum voor Beroepsziekten, Meibergdreef 91105 AZ Amsterdam, Nederland

Correspondentieadres: s.tamminga1@amsterdamumc.nl sector, beroep en provincie. Het aantal beroepsziektemeldingen NCVB werd vergeleken met surveillancedata van COVID-19 in Nederland, zoals gepubliceerd door het RIVM. ${ }^{1}$ De RIVM-surveillance heeft als doel zicht te houden op de spreiding van COVID-19 in Nederland en bevat onder andere informatie verkregen vanuit bron- en contactonderzoek (BCO) en registratiegegevens vanuit de medische sector. In de BCO-uitvraag wordt ook gevraagd naar de omstandigheden waaronder mensen denken besmet te zijn geworden, bijvoorbeeld in de thuissituatie of op het werk.

\section{Resultaten}

In totaal zijn er door 146 bedrijfsartsen 1088 meldingen van COVID-19 binnengekomen bij het NCVB in de periode april-oktober 2020. Ten opzichte van het totaal aantal meldingen in dezelfde periode is dit $47 \%$, waarbij tot nu toe de meeste meldingen in de maanden mei (relatief) en juni (absoluut) gedaan zijn (figuur 1). Verreweg de meeste meldingen zijn gerapporteerd in de sector gezondheidszorg en maatschappelijke dienstverlening en dan vooral in de zorgen verpleeghuizen (770 meldingen; $71 \%$ van het totaal aantal meldingen) en ziekenhuizen (231;21\%) (tabel 1). De werknemers van wie melding werd gemaakt zijn gemiddeld 45 jaar (standaarddeviatie 12,9) en 146 (13\%) van hen zijn man (tabel 1). In zorg- en verpleeghuizen werd in 538 van de 770 meldingen (70\%) onbeschermd contact met een COVID-19-patiënt gerapporteerd. In de totale groep werd in 42 van de 1088 meldingen (4\%) aangegeven dat werknemers zijn geïnfecteerd terwijl gebruik werd gemaakt van persoonlijk beschermingsmiddelen.

Uit de surveillance van het RIVM blijkt dat in de periode 1 juni-25 oktober in totaal 41.274 medewerkers in de zorg, handhaving of met een contactberoep positief zijn getest op COVID-19. Of deze besmetting op het werk heeft plaatsgevonden is niet na te gaan. ${ }^{1}$ Deze cijfers zijn door het RIVM verzameld in het kader van doelgroeponderzoek. Slechts een beperkt aantal beroepen is meegenomen in dit doelgroeponderzoek en biedt dus geen informatie over medewerkers uit andere beroepen die positief getest zijn op COVID-19. 
Tabel 1.

Karakteristieken van de beroepsziektemeldingen COVID-19 binnengekomen bij het NCVB periode april-oktober 2020

Beroepsziektemeldingen COVID-19 $\mathbf{N}$ NCVB periode april-oktober 2020

\begin{tabular}{|c|c|c|c|c|}
\hline \multicolumn{5}{|c|}{ Sociaal-demografische karakteristieken } \\
\hline \multicolumn{3}{|l|}{ Leeftijd (gemiddelde $( \pm$ SD)) } & $45(12,9)$ & 1088 \\
\hline \multicolumn{3}{|l|}{ Sekse (N (\%) man) } & $146(13)$ & 1088 \\
\hline \multirow[t]{6}{*}{ Provincie (N(\%)) } & \multicolumn{2}{|l|}{ Zuid-Holland } & $174(23)$ & \multirow[t]{6}{*}{765} \\
\hline & \multicolumn{2}{|l|}{ Gelderland } & $166(22)$ & \\
\hline & \multicolumn{2}{|l|}{ Brabant } & $77(10)$ & \\
\hline & \multicolumn{2}{|l|}{ Noord-Holland } & $91(12)$ & \\
\hline & \multicolumn{2}{|l|}{ Utrecht } & $102(13)$ & \\
\hline & \multicolumn{2}{|l|}{ Overig } & $160(20)$ & \\
\hline \multicolumn{5}{|l|}{ Werk-gerelateerde karakteristieken } \\
\hline \multirow[t]{7}{*}{ Economische sector $(\mathrm{N}(\%))$} & \multirow{3}{*}{$\begin{array}{l}\text { Gezondheidszorg en } \\
\text { maatschappelijke dienstverlening }\end{array}$} & Zorg- en verpleeghuizen & $770(71)$ & \multirow[t]{7}{*}{1088} \\
\hline & & Ziekenhuizen & $231(21)$ & \\
\hline & & Overige zorg & $38(3)$ & \\
\hline & \multicolumn{2}{|l|}{ Industrie } & $14(1)$ & \\
\hline & \multicolumn{2}{|l|}{ Onderwijs } & $10(1)$ & \\
\hline & \multicolumn{2}{|l|}{ Groot- en detailhandel } & $9(1)$ & \\
\hline & \multicolumn{2}{|l|}{ Overig } & $18(2)$ & \\
\hline \multirow[t]{6}{*}{ Beroepscategorie $(\mathrm{N}(\%))$} & \multicolumn{2}{|l|}{ Verzorgend personeel } & $710(65)$ & \multirow[t]{6}{*}{1088} \\
\hline & \multicolumn{2}{|c|}{ Vakspecialisten op het gebied van de gezondheidszorg } & $178(16)$ & \\
\hline & \multicolumn{2}{|c|}{ Specialisten op het gebied van de gezondheidszorg } & $72(7)$ & \\
\hline & \multicolumn{2}{|c|}{$\begin{array}{l}\text { Leidinggevende functies op het gebied van productie en } \\
\text { gespecialiseerde diensten }\end{array}$} & $17(2)$ & \\
\hline & \multicolumn{2}{|c|}{ Huishoudelijke hulpen en schoonmakers } & $17(2)$ & \\
\hline & \multicolumn{2}{|l|}{ Overig } & $94(9)$ & \\
\hline \multirow{3}{*}{$\begin{array}{l}\text { Mogelijke besmetting COVID-19 } \\
(\mathrm{N}(\%))\end{array}$} & \multirow{3}{*}{$\begin{array}{l}\text { Contact met geïnfecteerde } \\
\text { patiënt of collega }\end{array}$} & Onbeschermd contact & $704(65)$ & \multirow[t]{3}{*}{1088} \\
\hline & & Beschermd contact & $42(4)$ & \\
\hline & & Weet niet/ onbekend & $342(31)$ & \\
\hline
\end{tabular}

\section{Discussie}

Het aantal beroepsziektemeldingen van COVID-19 bij het NCVB is 1088 terwijl het aantal zorgmedewerkers, medewerkers in handhaving of medewerkers met een contactberoep die positief op COVID-19 getest zijn 41.274 is. Het aantal beroepsziektemeldingen is ten minste 38 keer lager dan het aantal positief geteste zorgmedewerkers, medewerkers in handhaving en medewerkers met een contactberoep. Daarnaast zijn bij het NCVB, voor enkele sectoren, zoals horeca en handhaving slechts enkele beroepsziektemeldingen van COVID-19 binnengekomen, terwijl men op basis van een risicoanalyse in deze beroepen veel meer meldingen zou verwachten. ${ }^{4}$

Een verklaring voor deze mogelijke onderrapportage is dat het melden van een beroepsziekte een persoonlijke afweging is van een bedrijfsarts aan de hand van een stappenplan terwijl het in de RIVM-surveillance om een meldingsplichtige A-ziekte gaat. Vanuit de Wet Publieke Gezondheid moet iedere bevestigde COVID-19-infectie bij de Gemeentelijke gezondheidsdienst (GGD) gemeld worden en wordt er een BCO-uitvraag gedaan. Het doel van deze verplichte registratie is om de spreiding van het virus in de maatschappij in te perken en is niet gekoppeld aan een compensatieregeling. Dit in tegenstelling tot landen zoals Italië. In Italië kan er een recht zijn op financiële compensatie door het stellen van de diagnose beroepsziekte, wat tot een overschatting kan leiden van het daadwerkelijk aantal beroepsziekten. ${ }^{5,6}$ Daarentegen kunnen in de Nederlandse situatie de beperkte toegang tot bedrijfsartsen, zoals bij zelfstandigen, het selectief meldgedrag van een bedrijfsarts ${ }^{7}$, of de omstandigheid dat de COVID-19-besmetting niet gezorgd heeft voor klachten of verzuim, leiden tot een onderschatting van het aantal beroepsziekten door COVID-19. Echter alle gegevensbronnen over werkgerelateerde COVID-19 
Percentage COVID-19-meldingen ten opzichte van alle beroepsziektemeldingen per maand

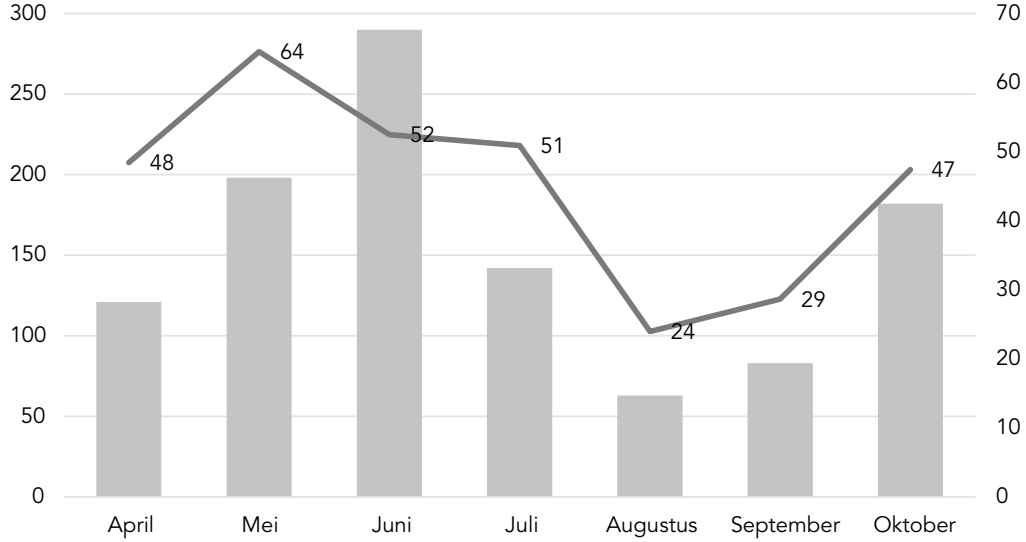

Figuur 1. Staafdiagram: het aantal beroepsziektemeldingen COVID-19 per maand; donkere lijn: het percentage COVID-19 beroepsziektemeldingen ten opzichte van het totaal aantal beroepsziektemeldingen per maand

vergroten het inzicht in het voorkomen van werkgerelateerde COVID-19 en daarmee de mogelijkheden voor het inzetten van preventieve maatregelen, zoals betere bronmaatregelen (thuis blijven bij klachten, laagdrempelig testen, deurbeleid en triage), collectieve maatregelen (afstand houden, handen wassen, fysieke barrière) en persoonlijke beschermingsmiddelen (mondneusmaskers en aanvullende maatregelen zoals face shields).

Het raadplegen van verschillende bronnen voor het in kaart brengen van beroepsziekten, zoals zelfrapportage door werkenden (bijvoorbeeld Nederlandse Enquête Arbeidsomstandigheden (NEA) ${ }^{8}$, CBS, compensatieclaims en beroepsziektemeldingen door bedrijfsartsen (NCVB) is een start om inzicht te verkrijgen in het voorkomen van werkgerelateerde COVID-19. Dit inzicht biedt mogelijkheden voor het inzetten van preventieve maatregelen, variërend van werkplek en werkorganisatieaanpassingen, persoonlijke beschermingsmiddelen, werk tot een toekomstig vaccinatiebeleid. Echter het ontslaat ons niet van acties gericht op kwaliteitsverbeteringen op het gebied van occupational health surveillance, zowel ten aanzien van een internationale definitie van werkgerelateerde
COVID-19, als de daadwerkelijke uitvoering van preventief medisch onderzoek. ${ }^{9}$

\section{Referenties}

1. Epidemiologische situatie COVID-19 Nederland tot en met 27 oktober 2020. Rijks Instituut voor Volksgezondheid en Milieu (RIVM).

2. Boschman JS, Brand T, Frings-Dresen MH, van der Molen HF. Improving the assessment of occupational diseases by occupational physicians. Occupational Medicine Med 2017;67:13-19.

3. Stappenplan registratie Corona Virus Ziekte 2019 als beroepsziekte R605. Gerda de Groene, Jaap Maas, Carel Hulshof en Henk van der Molen. Nederlands Centrum voor Beroepsziekten (NCVB). https://www.beroepsziekten.nl/sites/default/ files/documents/281020_stappenplan_melden_beroepsziekte_covid-19_cascode-605_update.pdf

4. Office for National Statistics. https://www.ons.gov.uk/ peoplepopulationandcommunity/healthandsocialcare/conditionsanddiseases

5. Marinaccio A, Boccuni F, Rondinone BM, et al. Occupational factors in the COVID-19 pandemic in Italy: compensation claims applications support establishing an occupational surveillance system. Occup Environ Med Epub ahead of print; doi:10.1136/ oemed-2020-106844.

6. Institute for Work and Health, Canada. https://www.iwh. on.ca/newsletters/at-work/101/what-research-can-do-estimating-role-of-workplaces-in-covid-19-transmissions [date of entry 1 October 2020].

7. Van der Molen HF, Omvlee L, Brand T, Frings-Dresen MHW. Perceived barriers and facilitators in the assessment of occupational diseases. Occupational Medicine 2018;68 (8):555-558.

8. Nationale Enquête Arbeidsomstandigheden. Enquête wordt uitgevoerd door TNO en CBS in samenwerking met SZW. https://www.monitorarbeid.tno.nl/nea.

9. Henk F van der Molen, Sanja Kezic, Gerda de Groene, Steven Visser, Marijke Schutte, Jaap Maas, Astrid de Wind, Sietske J Tamminga. Occupational COVID -19: what can be learned from registries of occupational diseases? Occup Environ Med Epub ahead of print. doi:10.1136/ oemed-2020-107121. https://oem.bmj.com/content/oemed/early/2020/11/06/ oemed-2020-107121.full.pdf 